\title{
The effect of changes in the amount of energy infused as volatile fatty acids on the nitrogen retention and creatinine excretion of lambs wholly nourished by intragastric infusion
}

\author{
By F. D. DeB. HOVELL, E. R. ØRSKOV, N. A. MACLEOD \\ AND I. MCDONALD \\ Rowett Research Institute, Bucksburn, Aberdeen AB2 9SB
}

(Received 11 October 1982-Accepted 8 April 1983)

\begin{abstract}
1. The nitrogen balance and creatinine excretion of wether lambs of $30-48 \mathrm{~kg}$, wholly nourished by the intragastric infusion of nutrients, were measured in two experiments. Four lambs were used in each experiment. In Expt 1 a constant amount of casein was infused into the abomasum (640 $\mathrm{mg} \mathrm{N} / \mathrm{kg}$ body-weight $(\mathrm{W})^{0.75}$ per d) and the amount of volatile fatty acids (VFA) infused into the rumen ranged from 0 to $670 \mathrm{~kJ} / \mathrm{kg} \mathrm{W}^{0.75}$ per $\mathrm{d}$ as six increments. Expt 2 was of similar design but two levels of casein were infused (530 and $1060 \mathrm{mg} \mathrm{N} / \mathrm{kg} \mathrm{W}^{0 \cdot 75}$ per d) and, with each level of casein, VFA infused ranged from 0 to $700 \mathrm{~kJ} / \mathrm{kg} \mathrm{W}^{0.75}$ per $\mathrm{d}$ as seven increments.

2. Daily creatinine excretion was not constant, but varied between 2-d means with standard deviations of between $7 \cdot 1$ and $16.5 \%$ (average $13.1 \%$ ) of the over-all means. There was an apparent correlation between creatinine excretion and the amount of energy infused in six out of eight lambs. There was no effect of the amount of casein infused.

3. In both experiments $\mathrm{N}$ balance was negative only when the amount of energy infused was substantially below published values for energy maintenance. In Expt $1, \mathrm{~N}$ equilibrium was calculated to be achieved at a gross (VFA plus protein) energy infusion level of 162 (SE 29) $\mathrm{kJ} / \mathrm{kg} \mathrm{W}^{0.85}$ per d. In Expt 2 it was observed that, at a given level of energy infusion, $\mathrm{N}$ retention was greater when the amount of energy had been increased from the previous level, than when it had been decreased.

4. It is concluded that the animal appears to allocate available amino acids to protein synthesis, rather than to oxidation, even when in negative energy balance. It is also concluded that the enhanced $\mathrm{N}$ retention observed when the amount of energy infused had been increased represented compensation after a period of energy restriction.
\end{abstract}

The development of the infusion technique whereby ruminant animals may be entirely sustained by an intraruminal infusion of volatile fatty acids (VFA) and minerals and an intra-abomasal infusion of protein, vitamins and trace minerals (Orskov et al. 1979b) has removed a number of constraints from the study of ruminant nutrition. In particular, the elimination of the rumen microbial population has greatly simplified the study of protein requirements, for the existence of a microbial population in the rumen of a normally-fed ruminant introduces uncertainty into estimations of the amounts of amino acids supplied to the host animal. Furthermore, the fact that the normal microbial degradation of food within the rumen has an obligate and associated production of microbial protein, means that a minimum is set to the relative proportions of protein and energy absorbed by the host animal once it is weaned. The use of the infusion technique allows the relative amounts of protein and energy supplied to the host animal to be varied at will, and to be changed rapidly and predictably.

The objective of the two experiments to be described here was to use the infusion technique to study the effect of the amount of VFA supplied to the host animal as an energy source on $\mathrm{N}$ retention when protein was supplied in excess of our estimates of the requirement. Our own estimates of the maintenance requirement were used because it has recently been shown in this laboratory (Ørskov \& MacLeod, 1982; Hovell et al.1983) that the basal $\mathrm{N}$ excretion of both sheep and cattle is substantially greater than that predicted 
by the Agricultural Research Council (1980). A provisional account has been given of the first experiment (Hovell et al. 1981).

\section{EXPERIMENTAL}

\section{Animals}

Eight wether lambs of initially $30-42 \mathrm{~kg}$ and approximately 4-6 months of age were used (four in each of the two experiments). They had been fitted with a rumen cannula and abomasal catheter as described by Ørskov et al. $(1979 b)$. The lambs were weighed initially and all subsequent calculations based on these weights.

\section{Housing and management}

The lambs were housed in metabolism crates. Management of the infusion was essentially as described by MacLeod et al. (1982) and Ørskov et al. (1979b). The VFA and buffer solutions were prepared as described by MacLeod et al. (1982) and their infusion was continuous. Casein, which was used as a protein source, was prepared as described by MacLeod et al. (1982) and infused into the abomasum so that the total daily amount was infused in 22-23 h. The pH was checked twice daily and the osmotic pressure of the rumen contents on most days. Buffer volumes and quantities were adjusted if necessary. The VFA solution used contained acetic, propionic and $n$-butyric acids in the molar proportions 0.65 , 0.25 and 0.10 respectively. Minerals as a calcium phosphate, calcium carbonate and magnesium chloride were mixed with the VFA and together with the buffer solution (potassium and sodium bicarbonates and sodium chloride) were infused into the rumen. Vitamins were mixed with the casein, or given as a monthly intramuscular injection. Other mineral and trace elements were given as a daily dose directly into the abomasum. Details of the various preparations used are given by MacLeod et al. (1982). The infusion started when the lambs were still receiving solid food (dried-grass pellets) at about maintenance. The initial rate of infusion was started at approximately $125 \mathrm{~kJ} \mathrm{VFA} / \mathrm{kg} \mathrm{W}^{0.75}$ per $\mathrm{d}$ and in Expt 1 was built up over a period of $4 \mathrm{~d}$ to supply approximately $340 \mathrm{~kJ} / \mathrm{kg} \mathrm{W}^{0.75}$ per $\mathrm{d}$ as VFA, at which level it was held for a preliminary period of $10 \mathrm{~d}$. Solid food was removed on the 4th day of the preliminary period. Urine $\mathrm{N}$ excretion was found to stabilize rapidly and, therefore, in Expt 2 the preliminary period was reduced to $5 \mathrm{~d}$, at an initial VFA infusion equivalent to either 450 or $525 \mathrm{~kJ} / \mathrm{kg} \mathrm{W}^{0.75}$ per d.

\section{Collection of excreta}

The metabolism cages were fitted with a wire mesh or PVC-coated, expanded metal floor. Faeces and urine were caught in a fibreglass separator funnel which covered the entire floor area. Urine passed directly into a collection tray containing acid (acetic acid in Expt 1 and sulphuric acid in Expt 2). Urine was weighed, sampled and analysed from the $24 \mathrm{~h}$ total collection. Any faecal debris was removed from the urine by means of a nylon sieve and bulked with faeces caught in the separator funnel. Storage was in sealed containers in a refrigerator and analysis on samples bulked over 10-14 $\mathrm{d}$.

\section{Chemical analysis}

Urine samples were analysed directly for $\mathbf{N}$ using the automated Kjeldahl method of Davidson et al. (1970), and creatinine by the automated technique of Technicon Instruments Co. Ltd (1965) which utilizes the Jaffe reaction (Hawk et al. 1947). Faecal samples were analysed directly for $\mathrm{N}$, dried at $100^{\circ}$ for dry matter (DM) determination and ashed at $600^{\circ}$ for organic matter determination. 


\section{Treatments and design}

The two experiments were of similar design.

Expt 1. Four lambs were given a constant daily amount of casein per abomasum, equivalent to $640 \mathrm{mg} \mathrm{N} / \mathrm{kg} \mathrm{W}^{0.75}$ per d. Additional energy was infused into the rumen as VFA in amounts equivalent to approximately $0,120,230,340,450,560$ and $670 \mathrm{~kJ} / \mathrm{kg} \mathrm{W}^{0.75}$ per $\mathrm{d}$. This programme was started after the end of the $10 \mathrm{~d}$ preliminary period at $340 \mathrm{~kJ} / \mathrm{kg} \mathrm{W}^{0.75}$ per $\mathrm{d}$. At the end of the preliminary period the amount of energy infused as VFA was either dropped to zero (two lambs), or increased over 4 or $5 \mathrm{~d}$ to $670 \mathrm{~kJ} / \mathrm{kg} \mathrm{W}^{0.75}$ per d as VFA (two lambs). Each level was then maintained for $5 \mathrm{~d}$ and then stepped by $110 \mathrm{~kJ} / \mathrm{kg} \mathrm{W}^{0 \cdot 75}$ per $\mathrm{d}$ either up or down until all seven levels had been imposed. At the end of the experiment some observations were repeated. Reproducibility was good and the results were included in the analysis of the data.

Expt 2. Four lambs were given each of two levels of casein per abomasum which were equivalent to approximately 530 or $1060 \mathrm{mg} \mathrm{N} / \mathrm{kg} \mathrm{W}^{0.75}$ per $\mathrm{d}$. The infusion of casein was held constant while VFA was infused at each of the following rates $(0,75,150,250,350$, 450,575 and $700 \mathrm{~kJ} / \mathrm{kg} \mathrm{W}^{0.75}$ per d). The amount of VFA was held constant for $4 \mathrm{~d}$ and then stepped either up or down. The steps were made to every alternate level either up or down and were reversed when the extremes had been reached (thus the intended order was 450 (prelim), 250, 75, 0, 150, 350, 575 and $700 \mathrm{~kJ} / \mathrm{kg} \mathrm{W}^{0.75}$ per d, or 575 (prelim), 700,450 $250,75,0,150$ and $350 \mathrm{~kJ} / \mathrm{kg} \mathrm{W}^{0.75}$ per d). Two lambs (one at each protein level) were allocated to each programme. The amount of protein being infused was then abruptly changed and the amount of VFA then being infused maintained for a further $5 \mathrm{~d}$ before being increased or decreased as before.

\section{Statistical analysis}

$\mathrm{N}$ balance, when it changed, responded rapidly to changes in energy or protein level. Examination of the results showed that there were no obvious trends from day to day at each energy level. Therefore values from only the 1st day at each energy or protein level were excluded from the analysis, although values from even the 1st day after a change in energy level were usually typical as is demonstrated by Fig. 1 which shows the daily $\mathrm{N}$ balance (all days) for one lamb in Expt 2. The rapid stabilization in $\mathbf{N}$ balance after the abrupt change in the amount of protein infused is also noteworthy. The only other values excluded were those on the day of and day following any infusion malfunction (shown by open symbols in Fig. 1). For reasons which will be described, the $\mathrm{N}$ balance values were processed differently in the two experiments.

In Expt 1 exponential regressions of the form $y=A+B e^{(-C x)}$ were fitted to the data where $y$ represents $\mathrm{N}$ balance $\left(\mathrm{mg} / \mathrm{kg} \mathrm{W} \mathbf{W}^{0 \cdot 75}\right.$ per $\left.\mathrm{d}\right)$ and $x$ is the level of energy infusion $\left(\mathrm{kJ} / \mathrm{kg} \mathrm{W}^{0.75}\right.$ per d).

In Expt 2 these were replaced by quadratic regression equations of the form $y=A+B x+C x^{2}$, two equations being fitted to the data for the two levels of protein infused. Within each protein level, a separate regression was fitted dependent upon whether the daily amount of VFA infused was being increased or decreased. From the equations so obtained, the $\mathrm{N}$ balances at energy intakes of $100,200,400,600$ and $800 \mathrm{~kJ} / \mathrm{kg} \mathrm{W}^{0.75}$ per $\mathrm{d}$ were calculated (with the constraint that the values had to be calculated only at energy intakes within the range of the observed values). The values so calculated were then subjected to analysis of variance.

Analysis of creatinine excretion in each experiment was carried out on mean values for 2-d sub-periods within each treatment period in order to reduce the effects of short-term variability. The 2-d sub-periods excluded the 1st day of each main period at each energy or protein level as for $\mathrm{N}$ above. 


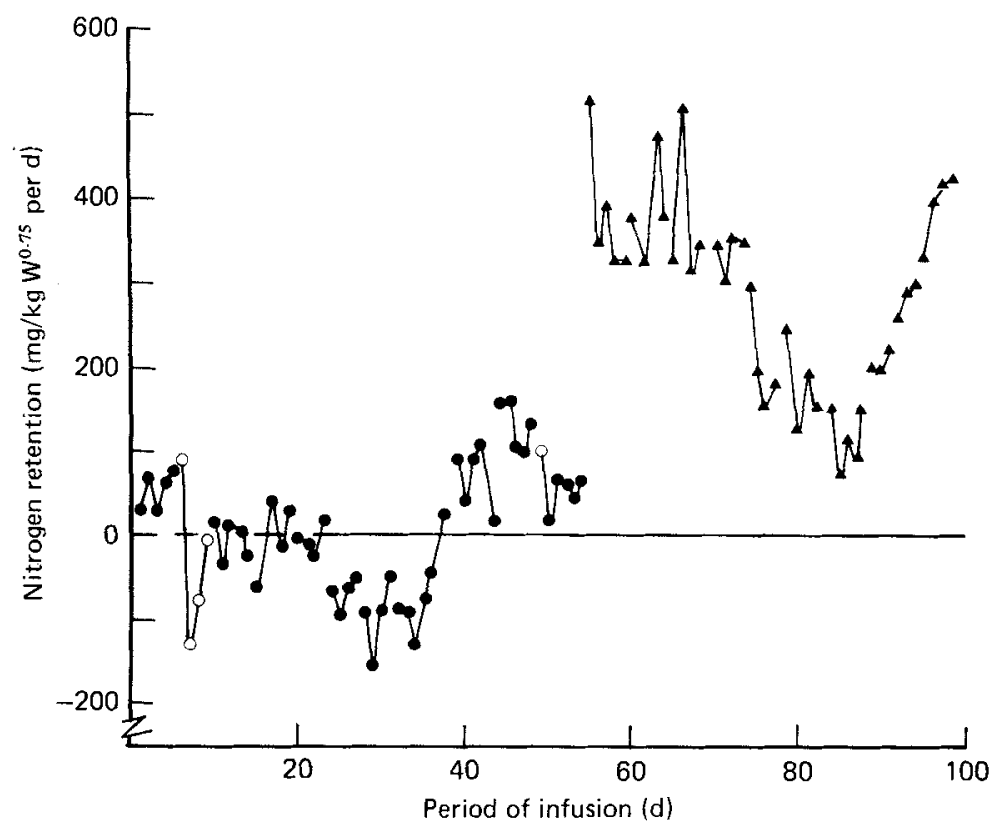

Fig. 1. Daily nitrogen retention $\left(\mathrm{mg} / \mathrm{kg}\right.$ body-weight $(\mathrm{W})^{0.75}$ per $\mathrm{d}$ ) by a wether lamb of $47 \mathrm{~kg}$ when given 530 (O) or 1060 (A) mg casein-N/ $/ \mathrm{k} \mathrm{W}^{0.75}$ per $\mathrm{d}$. Observations within each period are shown connected $(-)$, and days when an infusion malfunction occurred $(O)$.

\section{RESULTS}

Health and management of the lambs. The health of the experimental animals remained good throughout both experiments. However, at the end of the second experiment, the lambs were found to be harbouring a Salmonella infection (group E, type S, muenster) which was located in the gastrointestinal tract. The lambs themselves appeared to be in good health (apart from the periodic production of black, liquid faeces) and at post mortem following slaughter there were no other signs of ill-health. Faeces resembling 'scour' had been observed previously and therefore were not always associated with detection of Salmonella organisms. Previously we had thought production of very wet faeces to have been associated with osmotic factors, since faeces from lambs on infusion contained 500-750 g ash $/ \mathrm{kg} \mathrm{DM}$. Lambs with Salmonella were treated with furazolidone (Neftin; Eaton Laboratories, Woking). No effects on $\mathrm{N}$ balance were observed and therefore the values were included in the analysis.

The abomasal catheters were, in all cases, trouble free. The rumen cannula of some lambs developed a 'leak' round the rim of the cannula. It was noticed that very full rumens were often associated with high osmotic pressures (above $400 \mathrm{mosmol} / \mathrm{l}$ ) and the difficulty with leaking cannulas was partially resolved by increasing the volume infused into the rumen (diluting the VFA and buffer solutions) so that up to $0.81 / \mathrm{kg} \mathrm{W}^{0.75}$ per $\mathrm{d}$ was infused into the rumen at high VFA levels. It was noticeable that there were distinct differences between individuals in their ability to be infused at the higher levels of VFA (1.5-2.0 times maintenance), and recent evidence from this laboratory (N. A. MacLeod, unpublished observations) has suggested that this may reflect different rates of VFA absorption by the animal. However, by adjustment of the volumes infused, and the amount of buffer infused, it was possible to keep rumen $\mathrm{pH}$ above approximately 6.0 and osmotic pressure below approximately 300 mosmol/l (Engelhardt, 1970). 


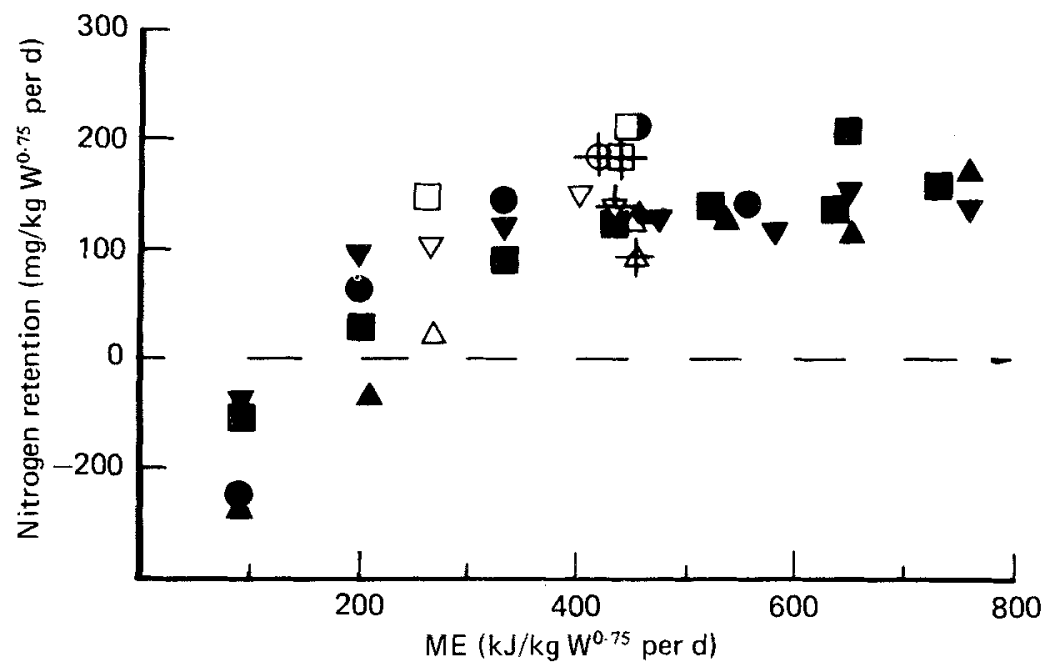

Fig. 2. Expt 1. The effect of the amount of energy infused $\left(\mathrm{ME} ; \mathrm{kJ} / \mathrm{kg}\right.$ body-weight $(\mathrm{W})^{0.75}$ per d) on nitrogen retention by wether lambs of $30-39 \mathrm{~kg}$ given $640 \mathrm{mg}$ casein- $\mathrm{N} / \mathrm{kg} \mathrm{W}^{\mathbf{0}} \cdot \mathbf{3}$ per d per abomasum. The means are shown for each period for individual lambs $(\mathbf{A} \mathbf{\nabla})$, for the preliminary period $(\oplus \notin$ 中田) and for additional periods at the end of the experiment $(\triangle \square \nabla)$.

On some occasions pump malfunctions, blocked infusion tubes and the normal hazards of experimentation, meant that the exact order of treatment planned was not always followed. This was because a malfunction at high levels of VFA infusion required several days to build up once more to the level of VFA infusion required. However, the general plan of stepping energy up and down was achieved and, with the exception of one lamb on Expt 1 (at the highest level of VFA), all intended levels of VFA infusion were imposed.

$N$ balance. Faecal losses of $\mathrm{N}$ were small, ranging between 3 and $28 \mathrm{mg} / \mathrm{kg} \mathrm{W}^{0.75}$ per d (the extreme values recorded), with a mean of 11 (sD 11) $\mathrm{mg} / \mathrm{kg} \mathrm{W}^{0 \cdot 75}$ per d. Faecal excretion was intermittent (averaging $2 \mathrm{~g} \mathrm{DM} / \mathrm{d}$ ) and therefore losses are difficult to relate to any particular collection period. There was no effect of level of casein infused on faecal $\mathrm{N}$ losses $\left(10\right.$ and $11 \mathrm{mg} / \mathrm{kg} \mathrm{W}^{0.75}$ per $\mathrm{d}$ for the low and high levels respectively, equal to $1-2 \%$ of the casein- $\mathrm{N}$ infused). For these reasons, $\mathrm{N}$ balance has been calculated as the difference between casein- $N$ infused and urinary $N$ excreted. Although a slight bias would have been introduced by this assumption, it is small, and does not affect the conclusions drawn from the results obtained.

The effect of total energy (VFA plus casein) infused on $N$ balance in Expt 1 ( $640 \mathrm{mg}$ casein$\mathrm{N} / \mathrm{kg} \mathrm{W}^{\mathbf{0} 75}$ per d) is shown in Fig. 2. In Fig. 2 the mean values (three to five observations) for each lamb at each energy level are plotted, together with the balance observed during the preliminary period (7-10 d). As can be seen, the values from the four lambs agree well. The energy intake at which $\mathbf{N}$ equilibrium was achieved was calculated for each lamb and is given in Table 1 . (The range of $119-245 \mathrm{~kJ} / \mathrm{kg} \mathrm{W}^{0 \cdot 75}$ per d may be partly due to variation in lean-body mass.) The mean value was 162 (SE 29) $\mathrm{kJ} / \mathrm{kg} \mathrm{W}^{0 \cdot 75}$ per $\mathrm{d}$. This is far below the estimate for the maintenance of energy equilibrium for infused lambs of $450 \mathrm{~kJ} / \mathrm{kg} \mathrm{W}^{0 \cdot 75}$ per d ( Orskov et al. 1979a) and shows that the lambs could maintain themselves in a state of positive $\mathbf{N}$ balance when in negative energy balance. Indeed negative $\mathbf{N}$ balance was only obtained at the lowest level of energy infusion (casein only, equivalent to $95 \mathrm{~kJ} / \mathrm{kg} \mathrm{W}^{0 \cdot 75}$ per d). Reproducibility was good as can be seen by the values obtained in the preliminary period and repeated observations at the end of the experiment (see Fig. 1).

Expt 2 was designed to obtain more information at low energy inputs. More observations 
Table 1. Expt 1. Level of energy (volatile fatty acids plus protein) infused ( $\mathrm{kJ} / \mathrm{kg}$ body-weight $(W)^{0.75}$ per $d$ ) at nitrogen equilibrium, and $N$ retention where 450 or $750 \mathrm{~kJ} / \mathrm{kg} W^{0 \cdot 75}$ per $d$ were infused into sheep

(Values were calculated from fitted curves)

\begin{tabular}{|c|c|c|c|c|}
\hline \multirow{2}{*}{$\begin{array}{l}\text { Lamb } \\
\text { number }\end{array}$} & \multirow{2}{*}{$\begin{array}{c}\text { Live wt } \\
\left(\mathrm{kg} \mathrm{W^{075 }} \text { per d) }\right.\end{array}$} & \multirow{2}{*}{$\begin{array}{l}\text { Energy infused at } \\
\mathrm{N} \text { equilibrium } \\
\left(\mathrm{kJ} / \mathrm{kg} \mathrm{W}^{0.75} \text { per } \mathrm{d}\right)\end{array}$} & \multicolumn{2}{|c|}{$\begin{array}{l}\mathrm{N} \text { retention }\left(\mathrm{mg} / \mathrm{kg} \mathrm{W} \mathrm{W}^{0 \cdot 7 \overline{5}} \text { per } \mathrm{d}\right) \\
\text { when energy infused was: }\end{array}$} \\
\hline & & & $450 \mathrm{~kJ} / \mathrm{kg} \mathrm{W}^{0-75}$ per d & $750 \mathrm{~kJ} / \mathrm{kg} \mathrm{W}^{0 \cdot 75}$ per d \\
\hline A & $15 \cdot 7$ & 154 & 173 & 188 \\
\hline B & 14.9 & 245 & 95 & 151 \\
\hline $\mathrm{C}$ & $13 \cdot 4$ & 119 & 138 & 144 \\
\hline D & $12 \cdot 8$ & 130 & 159 & 173 \\
\hline Mean (SE) & - & $162(29)$ & $141(17)$ & $164(10)$ \\
\hline
\end{tabular}

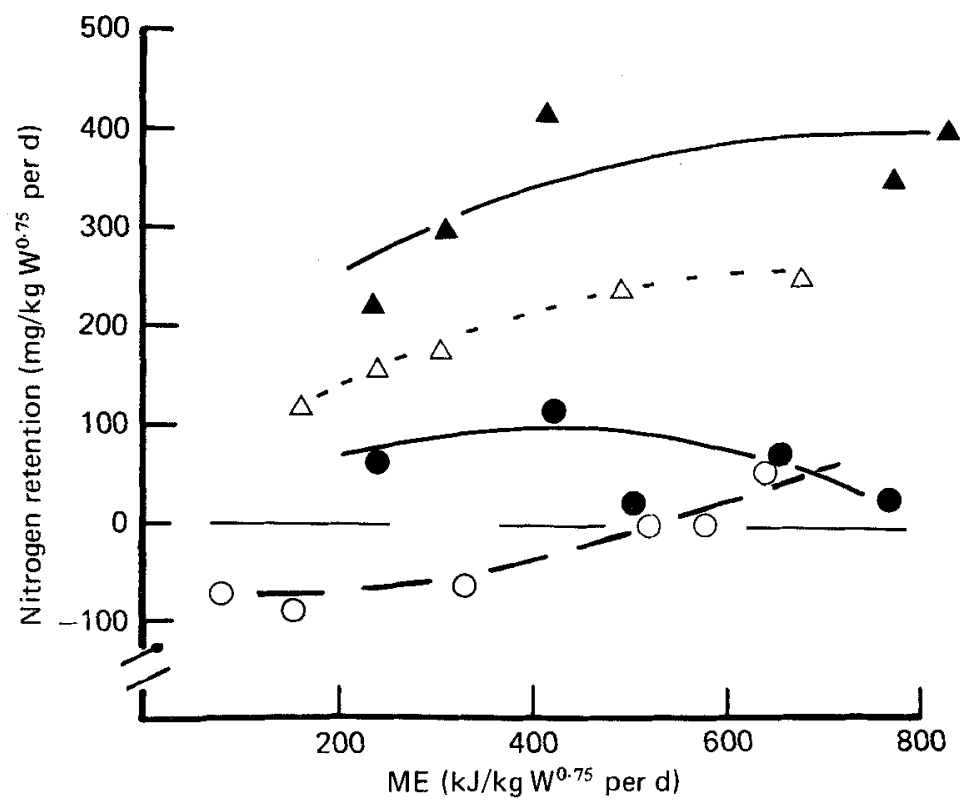

Fig. 3. Expt 2. The effect of the amount of energy infused (ME; $\mathrm{kJ} / \mathrm{kg}$ body-weight (W) ${ }^{0 \cdot 75}$ per d) on nitrogen retention (period means; $\mathrm{mg} / \mathrm{kg} \mathrm{W} \mathrm{W}^{0.75}$ per d) by a wether lamb of $47 \mathrm{~kg}$ given $530(0,0)$ or $1060(\triangle, \Delta) \mathrm{mg}$ casein- $\mathrm{N} / \mathrm{kg} \mathrm{W} \mathrm{W}^{077}$ per $\mathrm{d}$ when energy was being increased $(\boldsymbol{O}, \Delta)$ or decreased $(O, \triangle)$.

were made at low levels of energy infusion and the length of each period when casein only was infused was slightly increased (6-7 d compared with 5-6 d) in order to see whether there was any clear evidence of adaptation. None was observed. The variability of $\mathrm{N}$ balance in this experiment was too great to permit the fitting of exponential equations. Furthermore, it was observed that $\mathrm{N}$ retention was greater when the amount of VFA infused was being stepped up than when being stepped down. Therefore, the values from each animal were divided into two groups within each protein level (i.e. energy (VFA) being stepped up or down) and analysed as described on p. 333.

The average $\mathbf{N}$ retention measured for each energy level imposed together with the fitted regressions for one of the four lambs (lamb F) is shown in Fig. 3. The means of the values 


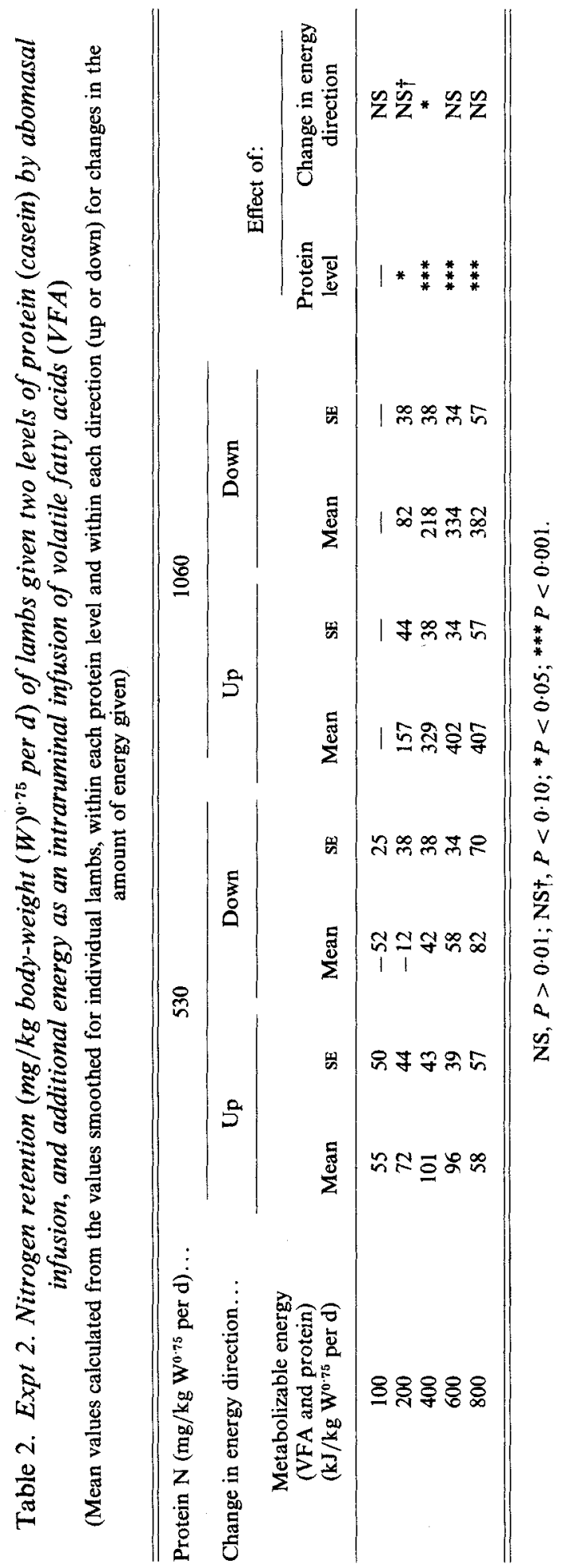


Table 3. Excretion of creatinine $\left(\mathrm{mg} / \mathrm{kg}\right.$ body-weight $(W)^{0.75} \mathrm{per} d$ ) of lambs maintained by total infusion

(Mean values and standard deviations)

\begin{tabular}{|c|c|c|c|c|c|c|c|}
\hline \multirow[b]{2}{*}{ Expt } & \multirow{2}{*}{$\begin{array}{l}\text { Lamb } \\
\text { number }\end{array}$} & \multirow{2}{*}{$\begin{array}{l}\text { Live wt } \\
\left(\operatorname{kg~W}^{6 \cdot 75}\right)\end{array}$} & \multirow[b]{2}{*}{$n$} & \multicolumn{2}{|c|}{$\begin{array}{c}\text { Creatinine } \\
\left(\mathrm{mg} / \mathrm{kg} \mathrm{W}^{0 \cdot 75} \text { per } \mathrm{d}\right)\end{array}$} & \multirow{2}{*}{$\begin{array}{c}\text { SD } \\
(\% \text { mean })\end{array}$} & \multirow{2}{*}{$\begin{array}{c}\text { Casein infused } \\
\left(\mathrm{mg} / \mathrm{kg} \mathrm{W}^{0} 7 \overline{5} \text { per } \mathrm{d}\right)\end{array}$} \\
\hline & & & & Mean & SD & & \\
\hline 1 & $\begin{array}{l}\text { A } \\
\text { B } \\
\text { C } \\
\text { D }\end{array}$ & $\begin{array}{l}15 \cdot 7 \\
14 \cdot 9 \\
13 \cdot 4 \\
12 \cdot 8\end{array}$ & $\begin{array}{l}29 \\
52 \\
46 \\
48\end{array}$ & $\begin{array}{l}52 \\
51 \\
67 \\
61\end{array}$ & $\begin{array}{l}8 \cdot 6 \\
6 \cdot 3 \\
4 \cdot 8 \\
9 \cdot 4\end{array}$ & $\begin{array}{r}16 \cdot 5 \\
12 \cdot 4 \\
7 \cdot 2 \\
15 \cdot 4\end{array}$ & $\begin{array}{l}640 \\
640 \\
640 \\
640\end{array}$ \\
\hline 2 & $\begin{array}{l}E \\
F \\
G \\
H\end{array}$ & $\begin{array}{l}16 \cdot 9 \\
18 \cdot 4 \\
16 \cdot 5 \\
18 \cdot 0\end{array}$ & $\begin{array}{l}55 \\
33 \\
37 \\
52\end{array}$ & $\begin{array}{l}45 \\
54 \\
44 \\
56\end{array}$ & $\begin{array}{l}6 \cdot 1 \\
7 \cdot 1 \\
7 \cdot 1 \\
9 \cdot 2\end{array}$ & $\begin{array}{l}13 \cdot 6 \\
13 \cdot 2 \\
16.1 \\
16.4\end{array}$ & $\begin{array}{l}541 \\
549 \\
526 \\
527\end{array}$ \\
\hline 2 & $\begin{array}{l}\mathrm{E} \\
\mathbf{F} \\
\mathbf{G} \\
\mathbf{H}\end{array}$ & $\begin{array}{l}16 \cdot 9 \\
18 \cdot 4 \\
16 \cdot 5 \\
18 \cdot 0\end{array}$ & $\begin{array}{l}35 \\
58 \\
54 \\
40\end{array}$ & $\begin{array}{l}50 \\
57 \\
48 \\
54\end{array}$ & $\begin{array}{l}6 \cdot 7 \\
6 \cdot 1 \\
6 \cdot 6 \\
4 \cdot 7\end{array}$ & $\begin{array}{r}13.4 \\
10.7 \\
13.8 \\
8.7\end{array}$ & $\begin{array}{l}1047 \\
1041 \\
1079 \\
1089\end{array}$ \\
\hline
\end{tabular}

calculated from the fitted curves are given in Table 2. Two points emerge. First, as in Expt 1 , the lambs remained in positive $\mathrm{N}$ balance when they would have been in negative energy balance. Second, there was an effect on $\mathrm{N}$ balance of changes in the amounts of energy infused, dependent on whether energy was being increased or decreased. Thus, at a given level of VFA infusion, more $\mathrm{N}$ was retained when the amount of energy as VFA was being increased than when being decreased, and this effect was possibly greater at lower levels of VFA infusion (it should be noted, however, that the level of VFA infused was confounded with time). Although Table 2 shows that statistical significance $(P<0.05)$ was only reached at $400 \mathrm{~kJ} / \mathrm{kg} \mathrm{W}^{0.75}$ per $\mathrm{d}$, the over-all trend is clear.

Creatinine excretion. The average values obtained for creatinine excretion are given in Table 3. These were not constant over the experimental period as is indicated by the standard deviations which ranged from $7 \cdot 1$ to $16.5 \%$ (average $13.1 \%$ ) of their over-all means. The daily creatinine excretion of one lamb (lamb F) is plotted in Fig. 4 together with energy infused, $\mathrm{N}$ balance and urine volume. As can be seen, creatinine excretion and energy infused followed a very similar pattern. The relationship was examined in more detail by the regression creatinine excretion $v$. energy infused. The results from Expt 2 showed no evidence of any effect of protein level or of the direction in change of energy level. The pooled values for each animal were therefore used in the calculations of the regression coefficients of creatinine excretion on energy infused given in Table 4, together with the same regression coefficients calculated from Expt 1 . For six of the eight lambs the regression coefficient was significant statistically. The coefficients differed significantly between animals.

\section{DISCUSSION}

\section{Creatinine excretion}

The relation between creatinine excretion and the amount of energy infused is difficult to explain. Sheffy et al. (1979) reported that obese women had a lower creatinine excretion when daily energy intake was reduced from $167 \mathrm{~kJ} / \mathrm{kg}$ body-weight to $38 \mathrm{~kJ} / \mathrm{kg}$ body-weight and that this did not depend on protein intake. However, no details were given. Garlick et al. (1980) also made a similar observation, for when their subjects were given either $2 \cdot 1 \mathrm{MJ}$ 

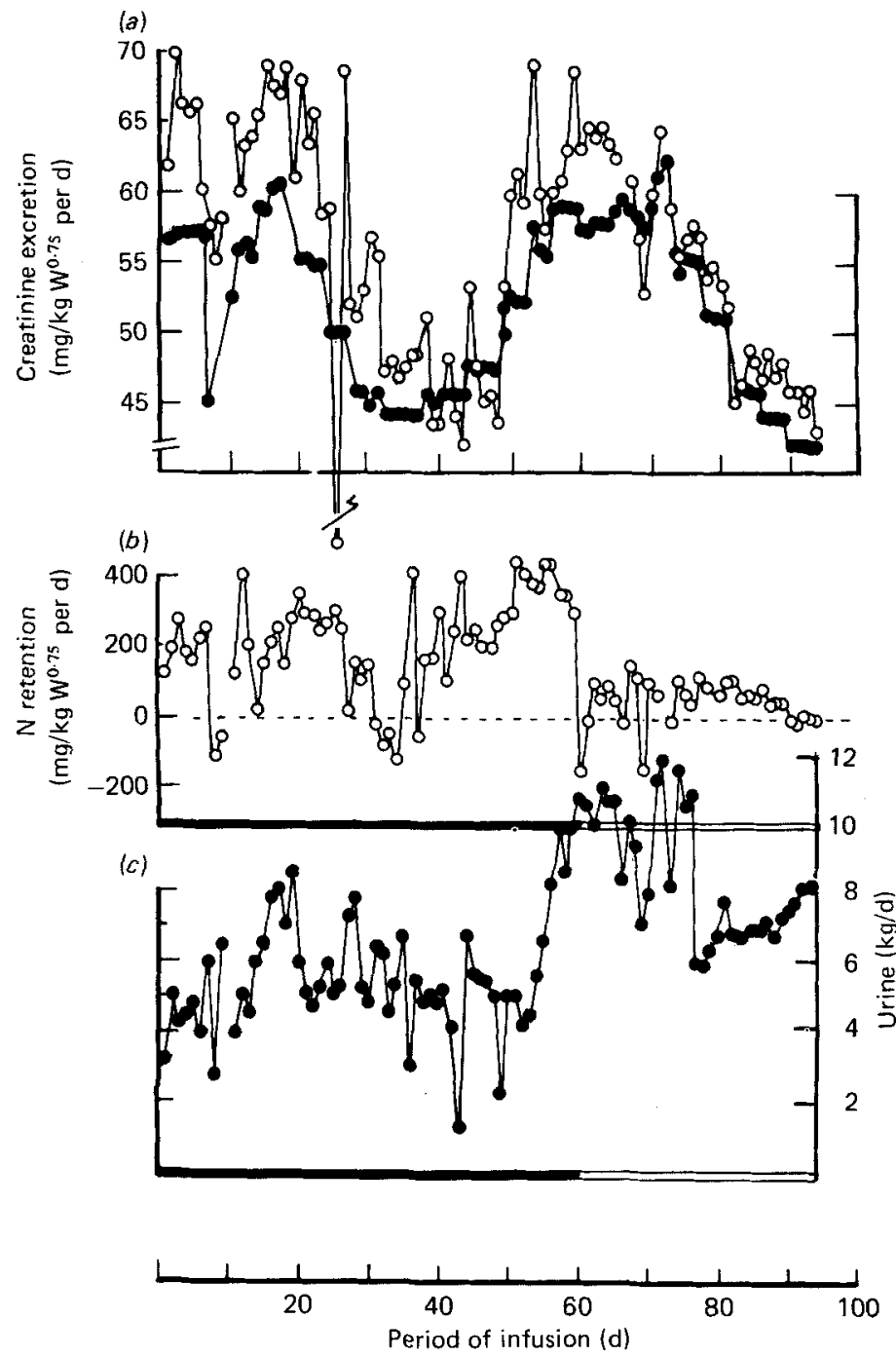

Fig. 4. Expt 2. (a) Daily excretion of creatinine $\left(O ; \mathrm{mg} / \mathrm{kg}\right.$ body-weight $(\mathrm{W})^{0.75}$ per $\left.\mathrm{d}\right)$ and the amount of energy infused $(O ; \mathrm{kJ} / \mathrm{kg} \mathrm{W0} \cdot 75$ per d) of a $48 \mathrm{~kg}$ wether lamb (lamb $\mathrm{F}$ ). (b) Daily nitrogen retention $\left(O ; \mathrm{mg} / \mathrm{kg} \mathrm{W}^{0.75}\right.$ per d) and $(c)$ urine $(O ; \mathrm{kg} / \mathrm{d})$ of a $48 \mathrm{~kg}$ wether lamb (lamb F) when given 1060 ( ) or 530 ( $) \mathrm{mg}$ casein-N/kg W0.75 per d per abomasum.

with $50 \mathrm{~g}$ protein or $2 \cdot 1 \mathrm{MJ}$ with no protein, creatinine excretion was reduced in both groups when compared with an initial period when $8.0 \mathrm{MJ}$ and $70 \mathrm{~g}$ protein were given. In the experiments reported here, confounding factors are introduced by the facts that increased $\mathrm{N}$ retention and greater urine volumes were also associated with increases in the amount of energy infused (initial difficulties in the maintenance of higher levels of energy infusion (as VFA) were resolved by increasing the volumes of the infusates). However, as can be seen from Fig. 4, urine volumes were not reflected by creatinine excretion in the first 'pulse' of high creatinine excretion, and $\mathrm{N}$ retention remained relatively constant during the second 'pulse' of high creatinine excretion. Thus, when creatinine excretion was plotted $v . \mathrm{N}$ retention or urine volume, there were no clear relationships. Therefore any association with 
Table 4. The relationship between creatinine excretion ( $\mathrm{mg} / \mathrm{d}$, dependent variable) and total energy infused ( $M J / d$, independent variable) expressed as the linear regression coefficient (b)

\begin{tabular}{cccccc}
\hline \hline Expt & Lamb & $n \dagger$ & $\begin{array}{c}\text { Change in } \\
\text { creatinine } \\
\text { (mg/MJ per d) } \\
\text { (b) }\end{array}$ & SE & $\begin{array}{c}\text { Statistical significance } \\
\text { of linear regression } \\
\text { coefficient (b) }\end{array}$ \\
\hline 1 & A & 13 & $37 \cdot 2$ & $10 \cdot 8$ & $* *$ \\
& B & 24 & $16 \cdot 8$ & 4.9 & $*$ \\
& C & 19 & $0 \cdot 8$ & $5 \cdot 3$ & NS \\
2 & D & 21 & $16 \cdot 1$ & $9 \cdot 4$ & $*$ \\
& E & 26 & 12.9 & 5.9 & $* * *$ \\
& F & 23 & $34 \cdot 0$ & $9 \cdot 0$ & $* * *$ \\
\hline
\end{tabular}

NS, $P>0.01 ; * P<0.05 ; * * P<0.01 ; * * * P<0.001$.

$\dagger$ Regression calculated from $n$ observations, each the mean of two consecutive days.

protein accretion or with a flushing effect of the kidneys processing different volumes of urine can probably be excluded. The urine was collected in acid and since it was analysed for creatinine in batches some samples were 2 or 3 weeks old on analysis, which presumably would have given ample time for the conversion on any creatine to creatinine. We are, therefore, unable to distinguish between creatinine and creatine excretion. With this reservation, it is clear that if creatinine (and possibly creatine) excretion is a reflexion of the creatine pool size (Crim et al. 1976), then creatine pool size or pool turnover can vary even when protein intake is very constant.

We have not previously measured regular fluctuations in creatinine of the order reported here. Creatinine excretion by dairy cows (collected and analysed in a similar way) was much more constant (Ørskov \& MacLeod, 1982) and did not show any relationship with energy infused and we are unable to arrive at any conclusions as to why the fluctuation in creatinine-creatine excretion occurred in the lambs. We can only report that it did occur, and agree with Crim et al. (1976) that creatinine excretion cannot be used as an index of muscle mass (it is unlikely that muscle mass fluctuated as did creatinine excretion), and probably not as an index of basal N metabolism (Ørskov \& MacLeod, 1982).

\section{$N$ utilization}

Two points are demonstrated by the results obtained for $\mathrm{N}$ balance. First, $\mathrm{N}$ retention remained positive even when energy balance must have been negative. Second, that after a period of depletion, or restricted $\mathrm{N}$ accretion when energy was restricted, there was evidence of a repletion or compensation.

The fact that $\mathrm{N}$ retention remained positive even when the lambs must have been in negative energy balance is in agreement with observations on dairy cows also made in this laboratory (Ørskov et al. 1983). The intercept of $\mathrm{N}$ equilibrium at 162 (SE 29) $\mathrm{kJ} / \mathrm{kg}$ $\mathrm{W}^{0.75}$ per $\mathrm{d}$ (Table 1 ) is substantially below the energy maintenance requirement of $450 \mathrm{~kJ} / \mathrm{kg} \mathrm{W}^{0.75}$ per d obtained with totally infused lambs (Ørskov et al. 1979a) and below that of $306 \mathrm{~kJ} / \mathrm{kg} \mathrm{W}^{0 \cdot 75}$ per d calculated from the Agricultural Research Council (1980) estimate of fasting metabolism for a 6-month-old lamb and an assumed utilization of VFA for maintenance of 0.85 . Indeed, the actual catabolism of body energy reserves (presumably fat) would have been greater than implied by the simple calculation, for the amount of energy infused was calculated (conventionally) as the sum of VFA plus protein. This convention 
of summing the energy values of protein and non-protein sources is not followed by the animal, which appears to allocate amino acids for metabolism as amino acids with a high priority. Mean $\mathrm{N}$ retention in Expt 1 was 141 (SE 17) $\mathrm{mg} / \mathrm{kg} \mathrm{W}^{0.75}$ per $\mathrm{d}$ with an infused energy intake of $450 \mathrm{~kJ} / \mathrm{kg} \mathrm{W}^{0.75}$ per d (Table 1), $288 \mathrm{~kJ}$ more than the amount of energy infused at $\mathrm{N}$ equilibrium. The energy equivalent of the additional protein metabolized $(141 \mathrm{mg} \mathrm{N})$ between these two levels of energy ( 162 and $450 \mathrm{~kJ})$ would have been equivalent to approximately $25 \mathrm{~kJ}$ ( $7 \%$ of the energy difference).

Expt 2 confirmed that positive $\mathrm{N}$ balance was maintained well below energy equilibrium (Fig. 2), indeed two of the four lambs never went into negative $\mathrm{N}$ balance at the high level of protein $\left(1060 \mathrm{mg}\right.$ casein- $\mathrm{N} / \mathrm{kg} \mathrm{W}^{0.75}$ per d, equivalent to approximately $\left.150 \mathrm{~kJ}\right)$. This ability of sheep (Hovell et al. 1981) and cattle (Ørskov et al. 1983) to remain in positive $\mathrm{N}$ balance, when in negative energy balance, has important practical implications, for it implies that the composition of an animal can be changed provided it has the potential for protein accretion. Thus, given a potential for growth, it should be possible to increase lean-body mass and decrease body fat in an animal by feeding below energy maintenance, but with sufficient protein to ensure $\mathrm{N}$ retention.

Similar observations have been made with (obese) human beings. If the results of Garlick et al. (1980) are calculated as $\mathrm{N}$ balance and expressed on the same basis as those of the experiments reported here, then when their subjects had diets based on milk protein (assumed to be completely digestible), and were given daily (per $\mathrm{kg} \mathrm{W}^{0 \cdot 75}$ ) $259 \mathrm{~kJ}$ with $378 \mathrm{mg} \mathrm{N}$, the $\mathrm{N}$ balance can be calculated to have been -28 (SE 15$) \mathrm{mg} / \mathrm{kg} \mathrm{W}^{0.75}$ per d. When the ration was reduced to $68 \mathrm{~kJ}$ with $253 \mathrm{mg} \mathrm{N}$, then N balance was -32 (SE 15) $\mathrm{mg} / \mathrm{kg} \mathrm{W}^{0.75}$ per d. Reeds \& Garlick (1983) discuss this and other similar information obtained with obese humans, and comment ' Remarkably (perhaps because the subjects were obese) there was little change in $\mathrm{N}$ balance associated with substantial reductions in energy intake'. Our results obtained with sheep would suggest this conservation of protein to be normal.

The second point to be made from the experiments reported here was that which arose in Expt 2, namely that previous nutrition had a marked effect on $\mathrm{N}$ retention. As Fig. 2 and Table 2 show, there was an improvement in the efficiency of $\mathrm{N}$ retention when the amount of energy being infused had been increased when compared with $\mathrm{N}$ retention at a similar level of energy infusion when energy had been decreased.

Expt 2 was not designed to investigate compensation, and the effect only became apparent as the experiment progressed. Therefore, a small trial with a single lamb (lamb G) was undertaken. In this trial the amount of VFA infused was kept constant at approximately $450 \mathrm{~kJ} / \mathrm{kg} \mathrm{W}^{0.75}$ per $\mathrm{d}$ and $530 \mathrm{mg}$ casein N/kg W ${ }^{0.75}$ per $\mathrm{d}$ was infused for $7 \mathrm{~d}$, followed by $10 \mathrm{~d}$ when no protein was given, and then by a further $7 \mathrm{~d}$ when casein was again infused at the $530 \mathrm{mg} \mathrm{N}$ rate. $\mathrm{N}$ retention in the second (repletion) period of casein infusion was $62 \%$ greater than in the initial period (Table 5). There was no evidence of a time-effect during the $7 \mathrm{~d}$ repletion period and, as implied by the small standard error $\left(4 \mathrm{mg} \mathrm{N} / \mathrm{kg} \mathrm{W}^{0.75}\right.$ per d), $\mathrm{N}$ retention during repletion was very constant. Presumably, however, it would have declined eventually to the rate observed before depletion.

There was some indication in Expt 2 that enhanced $\mathrm{N}$ retention (during increases in energy supply), was not necessarily dependent upon a preceding period of actual depletion. This is shown by the response at the high level of protein infusion (Table 2, Fig. 2). Thus, there may also have been a true compensatory accretion, in which protein deposition was accelerated in order to compensate for a reduced rate of accretion during energy restriction. This interpretation can only be tentative since wool growth was not measured and the relative states of the various protein pools in different organs was not known. There is considerable literature on compensatory growth (for reviews, see Wilson \& Osbourn, 1960; 
Table 5. The retention of nitrogen from the intra-abomasal infusion of casein, before and after a $10 \mathrm{~d}$ period when no protein was infused

(Mean values with their standard errors for a $45 \mathrm{~kg}$ wether lamb)

\begin{tabular}{|c|c|c|c|c|c|c|c|}
\hline \multirow{3}{*}{$\begin{array}{l}\text { Period } \\
\text { of } \\
\text { experiment } \\
\text { (d) }\end{array}$} & \multirow[b]{3}{*}{$n$} & \multicolumn{3}{|c|}{$\begin{array}{c}\text { Energy infused } \\
\left(\mathrm{kJ} / \mathrm{kg} \mathrm{W}^{0-75} \text { per } \mathrm{d}\right)\end{array}$} & \multicolumn{3}{|c|}{$\begin{array}{c}\text { Casein infused } \\
\text { (mg N/kg W0.75 per d) }\end{array}$} \\
\hline & & \multicolumn{2}{|c|}{ VFA } & \multirow[b]{2}{*}{ Protein } & \multirow[b]{2}{*}{ Infused } & \multicolumn{2}{|c|}{ N Balance } \\
\hline & & Mean & $\mathbf{S E}$ & & & Mean & $\mathrm{SE}$ \\
\hline $1-7$ & 7 & 452 & (6) & 78 & 530 & 87 & (10) \\
\hline $8-17$ & 10 & 428 & (6) & 0 & 0 & -286 & (14) \\
\hline $18-24$ & 7 & 449 & (10) & 78 & 530 & 141 & (4) \\
\hline
\end{tabular}

W, body-weight; VFA, volatile fatty acids.

Allden, 1970; Reid \& White, 1977). However, in the majority of experiments food was allowed ad lib. during compensation and, therefore, changes in the intake of both energy and protein complicate interpretation. Ørskov et al. (1976) showed, in a controlled experiment, that lambs which had had a restricted intake of protein made more rapid gains when subsequently given a high-protein diet than did lambs which had not been previously restricted but given similar amounts of protein during the same period of growth. Comparable results were obtained by Golden et al. (1977) with malnourished children. They showed that a protein intake (rationed on a body-weight basis) which promoted a positive $\mathrm{N}$ balance when the child was in a malnourished state, resulted in a negative $\mathrm{N}$ balance after repletion despite the fact that the amount of protein per unit lean-body mass would, if anything, have been greater since the repleted child would have been fatter. An interesting feature of the results of Ørskov et al. (1976) is that the lambs which showed increased protein accretion during compensation (when given the high level of protein), had made gains in body protein when restricted and, thus, the enhanced protein accretion was a true compensation and not simply a repletion of losses of body protein. The indication in Expt 2 that an enhanced accretion was not necessarily dependent upon preceding depletion provides confirmation of this observation.

The mechanisms by which repletion and compensation are achieved are not understood. Protein accretion (or depletion) is the net result of the separate processes of synthesis and degradation and, as has been discussed by Reeds \& Garlick (1983), modification of the rates of either or both of these processes will affect the rate of accretion. Protein synthesis is large relative to changes in body protein status. For example, Reeds et al. (1981) showed that mature dairy cows sustained by total infusion, and synthesizing protein at the rates of 279 and $293 \mathrm{~g} \mathrm{~N} / \mathrm{d}\left(2.38\right.$ and $2.50 \mathrm{~g} \mathrm{~N} / \mathrm{kg} \mathrm{W}^{0.75}$ per d), made daily changes of +1.6 and $-3.0 \mathrm{~g} \mathrm{~N}$ respectively in body $\mathrm{N}$ balance. Synthesis rates in growing animals are greater; Lobley et al. (1982) reported protein synthesis rates of between $4 \cdot 16$ and $5.76 \mathrm{~g} \mathrm{~N} / \mathrm{kg} \mathrm{W}^{0.75}$ per $\mathrm{d}$ with growing steers, approximately double that of the dairy cows referred to previously. Thus, only small changes in the relative rates of synthesis or degradation of protein or both would be sufficient to account for large changes in $\mathrm{N}$ balance.

Whatever the mechanism, the results presented here demonstrate that when the animal is repleting or compensating, $\mathrm{N}$ retention at a given protein and energy intake will be greater than during normal growth. If this improvement is achieved by an increase in synthesis rate only, then it will only be observed if protein intake is not limiting for normal growth at the energy intake then obtaining (i.e. below the maximal protein synthesis rate possible from 
the amino acids supplied by that protein source at a given level). If the improvement in retention is achieved by a reduction in degradation, then it may occur irrespective of whether protein is limiting or not. Both the models suggested above assume that amino acids are only catabolized if they are surplus to requirements for the synthesis of protein. Circumstantial evidence for this last constraint is provided by the other finding of the experiments reported here, namely, that the animal allocates amino acids to the maintenance of body protein, and to protein accretion, with a high priority.

The authors wish to thank Dr F. White for the preparation of the animals and our colleagues in the Applied Nutrition and Analytical departments of the Rowett Research Institute for the chemical analysis of samples (in particular to Miss S. Gauld, Miss M. Annand, Miss L. Melvin and Miss N. Mossom) and to Dr P. J. Reeds and other colleagues for helpful criticism and discussion.

\section{REFERENCES}

Agricultural Research Council (1980). The Nutrient Requirements of Ruminant Livestock. Slough: Commonwealth Agricultural Bureaux.

Allden, W. G. (1970). Nutrition Abstracts and Reviews 40, 1167-1184.

Crim, M. C., Calloway, D. H. \& Margen, S. (1976). Journal of Nutrition 106, 371-381.

Davidson, J., Mathieson, J. \& Boyne, A. W. (1970). Analyst, London 95, 181-193.

Engelhardt, W. V. (1970). Physiology of Digestion and Metabolism in the Ruminant. Proceedings of the 3rd International Symposium. Cambridge. [A. T. Phillipson, editor]. Newcastle upon Tyne: Oriel Press.

Garlick, P. J., Clugston, G. A. \& Waterlow, J. C. (1980). American Journal of Physiology 238, E235-244.

Golden, M. H. N., Waterlow, J. C. \& Picou, D. (1977). Clinical Science and Molecular Medicine 53, 473-477.

Hawk, P. B., Oser, B. L. \& Summerson, W. H. (1947). In Practical Physiological Chemistry, p. 506. San Francisco: McGraw Hill Co.

Hovell, F. D. DeB., MacLeod, N. A., Stirton, R. A. \& Ørskov, E. R. (1981). Proceedings of the Nutrition Society 41, 27A.

Hovell, F. D. DeB., Ørskov, E. R., Grubb, D. A. \& MacLeod, N. A. (1983). British Journal of Nutrition 50, 173-187.

Lobley, G. E., Smith, J. S., Mollison, G., Connell, A. \& Galbraith, H. (1982). Proceedings of the Nutrition Society 41, 28A.

MacLeod, N. A., Corrigall, W., Stirton, R. A. \& Ørskov, E. R. (1982). British Journal of Nutrition 47, 547-552.

Ørskov, E. R., Grubb, D. A., Smith, J. S., Webster, A. J. F. \& Corrigall, W. (1979a). British Journal of Nutrition 41, 541-551.

Ørskov, E. R., Grubb, D. A., Wenham, G. \& Corrigall, W. (1979b), British Journal of Nutrition 41, 553-558.

Ørskov, E. R., McDonald, I., Grubb, D. A. \& Pennie, K. (1976). Journal of Agricultural Science, Cambridge 86, $411-423$.

Ørskov, E. R. \& MacLeod, N. A. (1982). British Journal of Nutrition 47, 625-636.

Ørskov, E. R., MacLeod, N. A., Fahmey, S., Istasse, L. \& Hovell, F. D. DeB. (1983). British Journal of Nutrition 50, 99-107.

Reeds, P. J. \& Garlick, P. J. (1983) Advances in Nutrition Research (In the Press.)

Reeds, P. J., Ørskov, E. R. \& MacLeod, N. A. (1981). Proceedings of the Nutrition Society 40, 50A.

Reid, J. T. \& White, O. D. (1977). Proceedings of the Cornell Nutrition Conference for Feed Manufacturers (1977), pp. 16-27.

Sheffy, P. S., Jung, R. G. \& James, W. P. T. (1979). Proceedings of the Nutrition Society 38, 140A.

Technicon Instruments Co. Ltd (1965). Technicon Methodology Sheet N-11 B. Basingstoke: Technicon Instruments Co. Ltd.

Wilson, P. N. \& Osbourn, D. F. (1960), Biological Reviews 35, 324-363. 